\title{
Turtle remains from the late Miocene of the Cessaniti area, southern Italy-insights for a probable Tortonian chelonian dispersal from Europe to Africa
}

\author{
Georgios L. Georgalis ${ }^{*}$, Gianni Insacco², Lorenzo Rook ${ }^{3}$, Filippo Spadola ${ }^{2,4}$ and Massimo Delfino ${ }^{1,5}$
}

\begin{abstract}
We here describe turtle remains from the late Miocene (Tortonian) of Cessaniti (Calabria, southern Italy), an area that recently has been palaeogeographically reconstructed as being, at that time of the Neogene, directly connected (or at least rather proximate) to northern Africa, instead of Europe. The material pertains to three different turtle clades, i.e., pan-trionychids, pan-cheloniids, and pan-geoemydids. Although the material is incomplete, it nevertheless permits a more precise identification for the pan-trionychid specimens, which are referred to the species Trionyx pliocenicus, as well as the pan-geoemydid, which is attributed to the genus Mauremys. Especially for the case of T. pliocenicus, the new Cessaniti specimens expand its geographic and stratigraphic distribution and further comprise the sole existing material known for this species, considering that its holotype and so far only known material is currently lost. Overall, besides its taxonomic significance, the Cessaniti chelonian assemblage affords the potential for important biogeographic implications, attesting that the lineages of Trionyx and Mauremys could have potentially used the Sicily-Calabria arch for their dispersal from Europe to Africa during the Tortonian. The new turtle specimens further complement the associated mammal remains in envisaging the Cessaniti assemblage as a mosaic of both African and Eurasian (Pikermian) faunal elements.
\end{abstract}

Keywords: Testudines, Trionyx, Mauremys, Pan-Cheloniidae, Miocene, Biogeography

\section{Introduction}

The palaeogeography of Europe and adjacent areas has been subjected to significant alterations throughout the Neogene (Rögl 1999; Meulenkamp and Sissingh 2003). On certain occasions, drastic palaeogeographic changes have facilitated waves of dispersals of vertebrate taxa from Africa to Europe during the Neogene, affecting tremendously the faunal composition of both continents, with new incoming immigrants drastically outcompeting autochthonous animals, occupying novel ecological niches, and reshaping

\section{Editorial handling: D. Marty.}

*Correspondence: dimetrodon82@gmail.com

1 Dipartimento di Scienze della Terra, Università di Torino, Via Valperga

Caluso 35, 10125 Turin, Italy

Full list of author information is available at the end of the article dramatically palaeonvironments and faunal composition (e.g., Rögl 1999; Delfino et al. 2003, 2013a; Koufos et al. 2003; Rook et al. 2006, 2008; Rage 2013; Georgalis et al. 2016a, 2019a, b). Two such, palaeogeography-driven, Neogene dispersal events are mostly known and have been more meticulously studied: one during the early Miocene (Burdigalian), when the Afro-Arabian plate collided with Eurasia, allowing direct terrestrial connection among the two areas on the east via the so-called Gomphotherium land bridge (Koufos et al. 2003, 2005; Georgalis et al. 2016a, 2019a) and another one during the latest Miocene (Messinian) that was facilitated by the Messinian Salinity Crisis, when big parts of the Mediterranean Sea dried out (Hsü 1972; Torres-Roig et al. 2017; Georgalis et al. 2019b; see Carnevale et al. 2019, for a recent overview of the Italian 
fossil record of the Messinian Salinity Crisis). Moreover, geological data and the fossil record also show different palaeogeographic reconstructions for the Aegean region, where the Greek mainland, islands (including also Crete), and Anatolia were united during the early Miocene (Lymberakis and Poulakakis 2010; Georgalis et al. 2016b), as well as the indication of unique insular environments ("palaeoislands") in the Gargano and Scontrone areas (Freudenthal 1971, 1972; Rook et al. 2006, 2008; Freudenthal and MartínSuárez 2010), as well as in the Tuscany area (Rook et al. 2006, 2008; Rook 2016), which are all now parts of the Italian mainland.

Interestingly, fossil evidence from southern Italy has recently allowed the identification of another, not yet so well-known palaeobioprovince testified by sites in Calabria and Sicily characterized by non-endemic mammals, counterparts of which were identified in both North Africa and Europe (Rook et al. 2008). The identification of the elephantid proboscidean Stegotetrabelodon syrticus (which is of clear African origin) in the late Miocene (Tortonian) of the Cessaniti area, Calabria, southern Italy, has led to the suggestion that, during that time interval, the Sicily-Calabria arch (Siculo-Calabrian arc) was united with northern Africa, forming in fact part of the latter continent and not Europe (Ferretti et al. 2003). Further finds of terrestrial mammals of Eurasian affinities in Cessaniti were envisaged to denote an expansion of these faunal elements towards Africa (Marra et al. 2011). In order to improve the knowledge of this palaeobioprovince, that has been based so far on mammals only, we here describe for the first time reptile finds from the Cessaniti area. This material, represented by turtle remains recovered from those localities, pertains to three different lineages and provides an opportunity to assess the previous palaeogeographic reconstructions and test the previously suggested biogeographic scenarios.

Institutional abbreviations MDHC, Massimo Delfino Herpetological Collection, University of Torino, Italy; MGP-PD Museo di Geologia e Paleontologia dell'Università di Padova, Padua, Italy; MGPT-PU Museo di Geologia e Paleontologia, Università degli Studi di Torino, Turin, Italy; MNHN, Muséum national d'Histoire naturelle, Paris, France; MSNC, Museo Civico di Storia Naturale di Comiso, Comiso, Italy; NHMW, Naturhistorisches Museum Wien, Vienna, Austria; NHMUK, Natural History Museum, London, United Kingdom.

\section{Materials and methods}

The turtle material described herein is curated at MSNC. All specimens originate from the area of Cessaniti, Vibo Valentia, Calabria, Italy. More specifically, within Cessaniti, the pan-cheloniid and most of the pan-trionychid remains originate from Cava Gentile, while the single pan-geoemydid specimen MSNC 4380 and the juvenile pan-trionychid costal MSNC 4591 originate from Cava Franzè. Part of the herein described material has been presented in the unpublished theses of Delfino (2002) and Chesi (2009). Comparative material of extinct and extant turtles belongs to the following collections: MDHC, MGP-PD, MGPT-PU, MNHN, NHMW, and NHMUK. Authorships of turtle clades follow Joyce et al. (2004).

\section{Geological and palaeoecological settings}

The Cessaniti fossiliferous area consists of different localities/quarries cropping out in the area between Capo Vaticano and Vibo Valentia on the Calabria Tyrrhenian coast (Gramigna et al. 2008; Marra et al. 2017). Among them, Cava Gentile has produced most of the vertebrate remains described so far (see Marra et al. 2017). This is also the case with the turtle finds that are presented in this paper (i.e., all turtle fossils originate from Cava Gentile, except for the Mauremys specimen MSCN 4380 and the Trionyx costal MSNC 4591 that both come from Cava Franzè). Both Cava Gentile and Cava Franzè are considered to be of Tortonian age (Carone and Domning 2007; Marra et al. 2017; Stara and Marini 2018). Several studies have dealt with the geology of the localities of the Cessaniti area during the past decades (Nicotera 1959; Ogniben 1973; Moncharmont Zei and Montcharmont 1987; Carone and Domning 2007; Gramigna et al. 2008; Marra et al. 2017). The most recent review of geology, palaeoenvironmental, and stratigraphic setting of the area is offered by Marra et al. (2017), where the age range of Cava Gentile, on the basis of magnetostratigraphic and biostratigraphic control, has been suggested to be within the range of 8.1 and 7.2 $\mathrm{Ma}$ (Marra et al. 2017).

The Cava Gentile quarry of Cessaniti has yielded an array of marine invertebrate taxa (e.g., Gramigna et al. 2008; Stara and Marini 2018), however, mammal finds are also known. Mammal finds comprise marine taxa such as the sirenian Metaxytherium and cetaceans (Neviani 1886; Carone and Domning 2007; Marra et al. 2016), but also terrestrial forms such as the proboscidean S. syrticus, the endemic rhinocerotid Ceratotherium advenientis, the giraffids Bohlinia and Samotherium, the bovid Tragoportax cf. rugosifrons, while (as yet undescribed) reports of smaller bovids and hippopotamids also exist (Ferretti et al. 2003; Marra et al. 2011; Marra 2018; Pandolfi et al. 2019). Fossil and sedimentological evidence (Marra et al. 2017) suggests that the palaeoenvironment of the Cessaniti area was a mosaic environment with open spaces, probably similar to the modern savannah, but less arid (in agreement with the environmental conditions of the so-called Pikermian biome). Finally, the greater mammal bone accumulation in sols during transgression events weakens the hypothesis of the carcasses casual sinking after a long floating in open sea (Marra et al. 2011), 
in favor of a scenario with remains transported from a nearby emerged land (Marra et al. 2017).

All (but two) among our described specimens come from the lowermost "transitional" sediments outcropping in the Gentile quarry exposures [unit CG.FL1 in Marra et al. (2017)], while the Trionyx specimen MSNC 4591 and the Mauremys one MSNC 4380 were collected in Franzé quarry from a level of dark argillaceous lagoonal

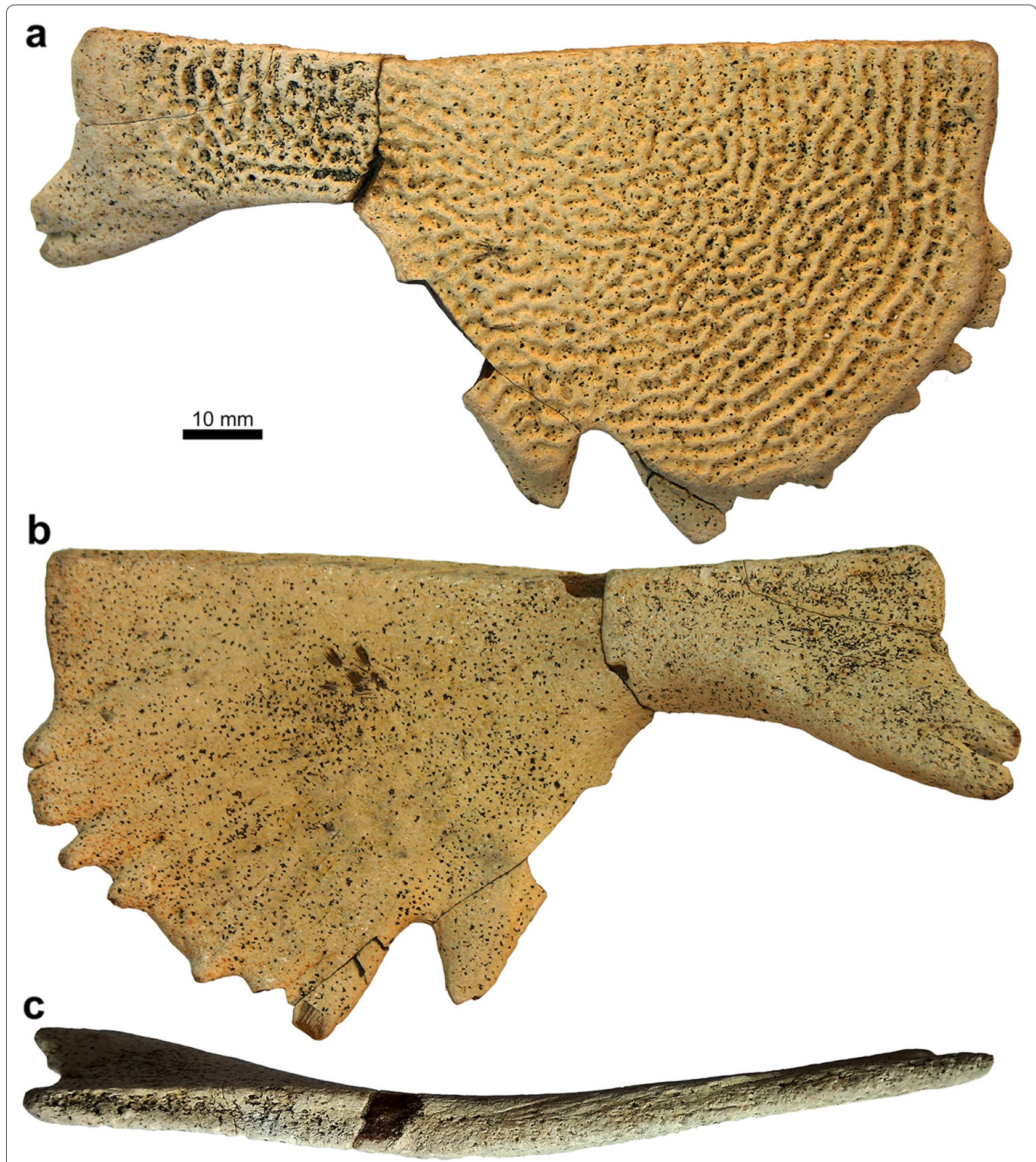

Fig. 1 Trionyx pliocenicus from Cessaniti; plastral material. Right hypoplastron (MSNC 4589) in ventral (a), dorsal (b), and anterior (c) views 


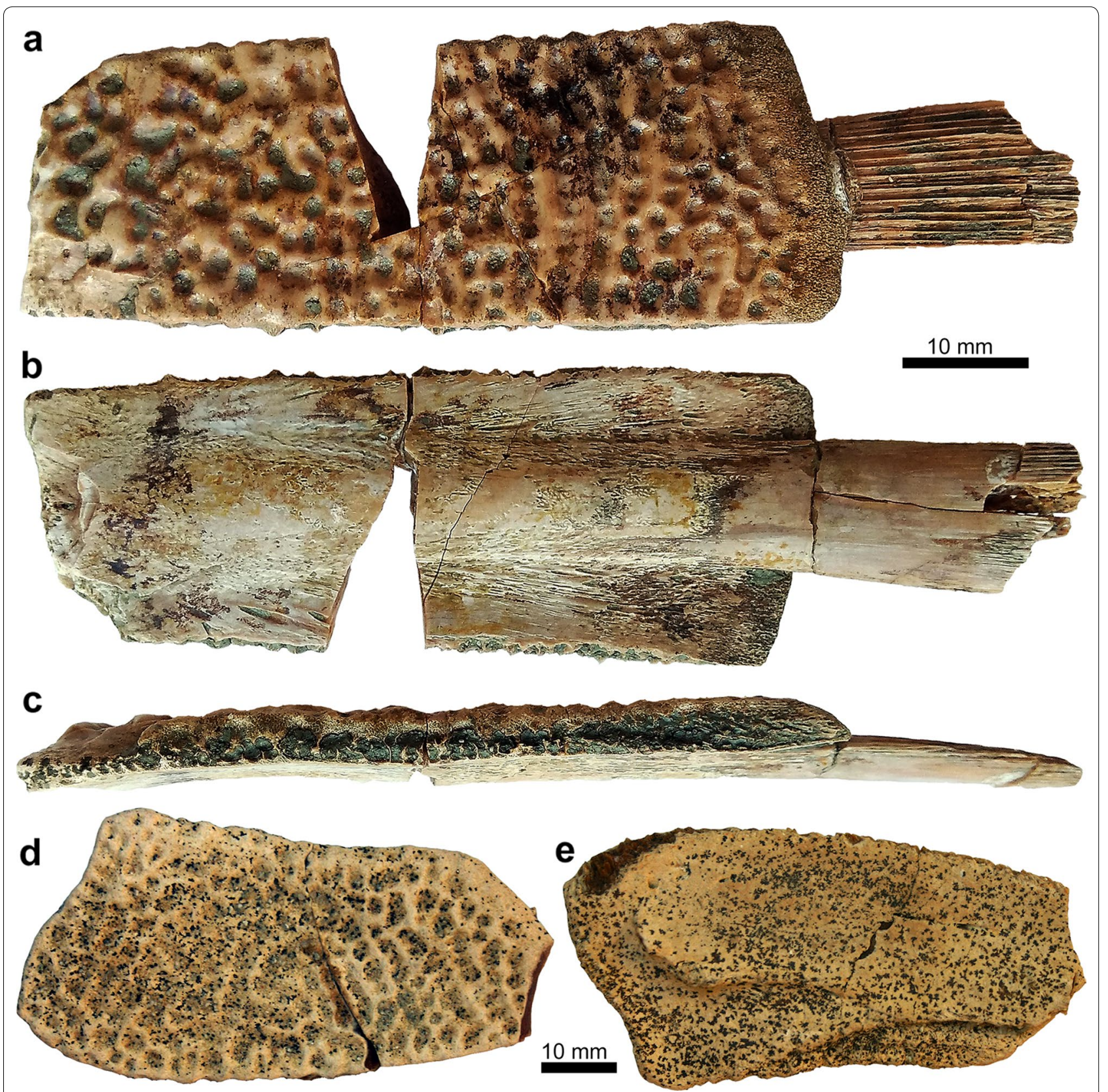

Fig. 2 Trionyx pliocenicus from Cessaniti; carapace material. a-c Costal (MSNC 4591) of a juvenile in dorsal (a), ventral (b), and lateral (c) views; d-e costal fragment (MSNC 4590) in dorsal (d) and ventral (e) views

sands which can be lithostratigraphically correlated to basal unit of Cava Gentile [unit CG.LG in Marra et al. (2017)]. The chronological attribution of the described turtles can be dated to around $8.0 \mathrm{Ma}$, being the provenance layer from the base of the sedimentary succession magnetostratigraphically correlated with normal Chron C4n (Marra et al. 2017).

\section{Systematic palaeontology}

Testudines Batsch, 1788

Pan-Trionychidae Joyce, Parham, and Gauthier, 2004

Pan-Trionychinae Georgalis and Joyce, 2017 


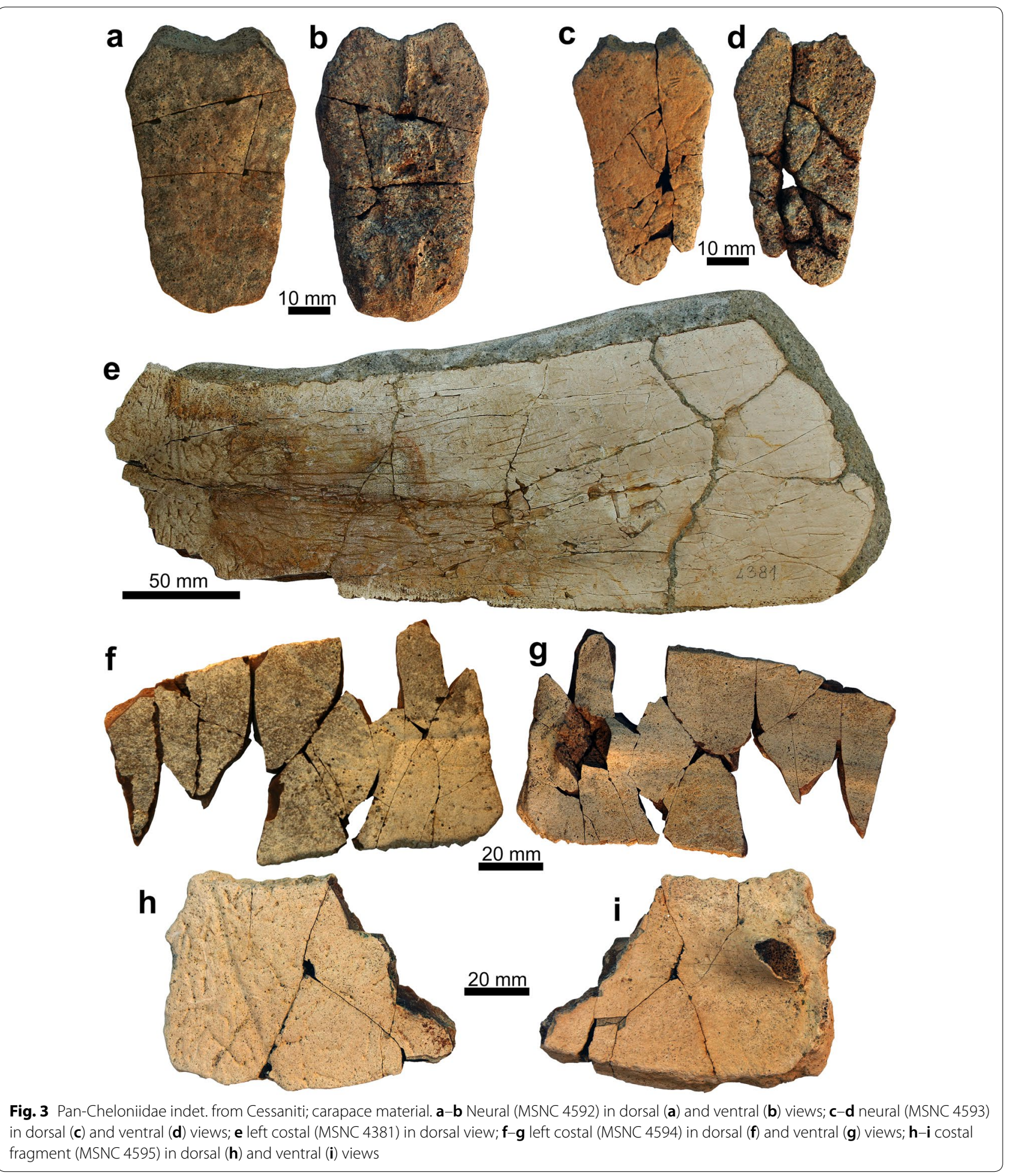




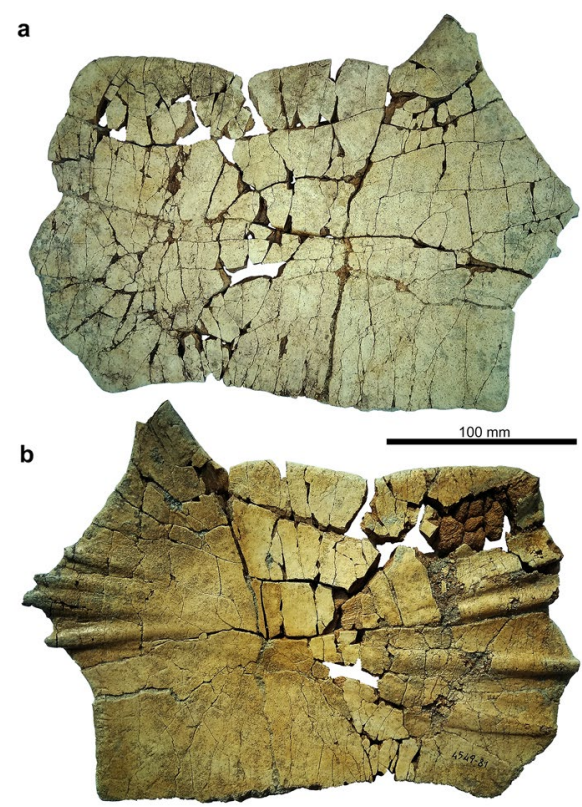

Fig. 4 Pan-Cheloniidae indet. from Cessaniti; plastral material. Right hyoplastron (MSNC 4549-81) in ventral (a) and dorsal (b) views

Trionyx Geoffroy Saint-Hilaire, 1809

Trionyx pliocenicus Fucini, 1912

Figures 1, 2

Material two costal fragments (MSNC 4590 and MSNC 4591) and a complete right hypoplastron (MSNC 4589).

\section{Description}

Hypoplastron MSNC 4589 is an almost complete right hypoplastron (Fig. 1). This element is relatively large with a maximum length of $113 \mathrm{~mm}$. It is moderately thick, with a maximum thickness of $7.8 \mathrm{~mm}$. The hypoplastron possesses two moderately developed lateral processes, whereas its medial hypoplastral processes are more numerous and prominent, facing in multiple different directions. More particularly, its two posteromedial hypoplastral processes (that adjust to the xiphiplastron) are large and relatively broad. The anteromedial hypoplastral processes are smaller and much closely located to one to each other, with the two anteriormost ones almost clustering together; all of them do not protrude significantly laterally and some of them are almost barely visible in dorsal view. The hypoplastron is entirely covered by prominent sculpturing across its whole ventral surface (Fig. 1a). This sculpturing pattern consists of a dense wave of ridges that becomes more prominent towards the edges of the element, and slightly fades out in its center. It seems that the hypoplastron was transversely sutured (but not fused) with the hyoplastron across its whole length.

Costals MSNC 4591 is a relatively small costal, pertaining to a juvenile individual, as it can be judged from the extended rib that protrudes well laterally from the costal $($ Fig. $2 \mathrm{a}-\mathrm{c})$. The costal is rather elongate and slender; it is $63 \mathrm{~mm}$ long (without the costal rib) and has a maximum width of $23.5 \mathrm{~mm}$. The specimen is moderately thick, with a thickness of around $4 \mathrm{~mm}$. The extended portion of the rib is relatively large, being $19 \mathrm{~mm}$ long and $12 \mathrm{~mm}$ wide. The specimen is covered by an extensive sculpturing on its dorsal surface (Fig. 2a). The sculpturing pattern is nevertheless different than that present in the above described hypoplastron and consists of dense honeycomb-like structures that are almost uniform throughout its surface and only seems to fade out at its lateral-most edge. MSNC 4590 is an isolated fragment of a (probably left) costal (Fig. 2d, e). The preserved element is moderately long, measuring $64 \mathrm{~mm}$ in length. Its lateral side is larger than its medial one. Similarly to the above

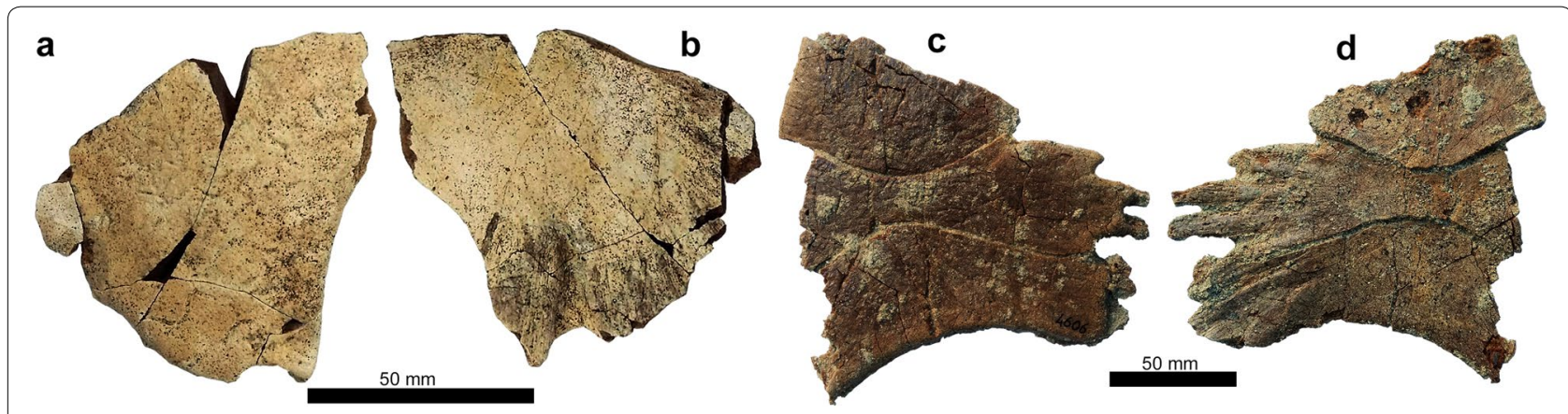

Fig. 5 Pan-Cheloniidae indet. from Cessaniti; plastral material. a-b Fragment of left hypoplastron (MSNC 4602) in ventral (a) and dorsal (b) views; c-d plastral fragment (MSNC 4606) in ventral (c) and dorsal (d) views 


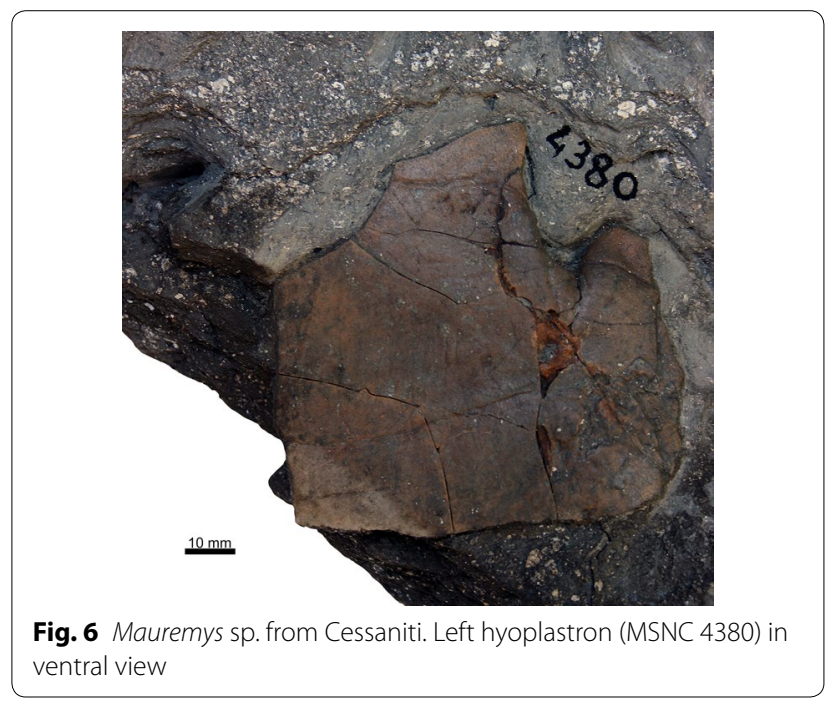

described costal, this element is also covered by extensive sculpturing on its dorsal surface (Fig. 2d); the sculpturing pattern consists, also in this costal fragment, of dense honeycomb-like structures. In ventral view, signs of an emerging costal rib are obvious near its lateral side.

Remarks The almost complete right hypoplastron can be referred to T. pliocenicus on the basis of its rather extensive plastral callosities, which are more prominent than Trionyx vindobonensis Peters, 1855 (the sole other European Neogene member of the genus Trionyx) and the extant Trionyx triunguis (Forskål, 1775) (see Georgalis and Joyce 2017). The holotype and only known specimen of T. pliocenicus was a relatively complete skeleton preserving the skull and much of the carapace, plastron, and appendicular remains, originating from the Pliocene of Mapesi, Tuscany, Italy (Fucini 1912; Georgalis and Joyce 2017). This specimen is currently considered lost, however, it was adequately described and figured by Fucini (1912), enabling, in any case, a proper understanding of its anatomical features (Georgalis and Joyce 2017). Besides the extent and prominence of its plastral callosities and the overall shape resemblance, conspecific affinities of the Cessaniti hypoplastron with T. pliocenicus can be further supported on the basis of a general geographic and stratigraphic rationale. As for the two isolated costal remains (MSNC 4590 and MSNC 4591), they are also tentatively assigned to the same taxon, again using a biogeographic rationale, further taking into consideration that late Miocene trionychid faunas from Europe were not much diversified and species-rich (Georgalis and Joyce 2017).
Pan-Cheloniidae Joyce, Parham, and Gauthier, 2004

Pan-Cheloniidae indet.

Figures 3, 4, 5

Material two neurals (MSNC 4592 and MSNC 4593), five costals (MSNC 4381, MSNC 4594, MSNC 4595, MSNC 4605, and MSNC 4607), a fragment of peripheral (MSNC 4604), a right hyoplastron (MSNC 4549-81), a left hypoplastron (MSNC 4602), a plastral fragment (MSNC 4606), and five shell fragments (MSNC 4581, MSNC 4597, MSNC 4599, MSNC 4600, MSNC 4601).

\section{Description}

Neurals The largest neural (MSNC 4592; Fig. 3a, b) has a length of $60 \mathrm{~mm}$ and a maximum width of $38.4 \mathrm{~mm}$, while the smaller one (MSNC 4593; Fig. 3c, d) has a length of $56.2 \mathrm{~mm}$ and a maximum width of $31.4 \mathrm{~mm}$. The thickness of both specimens varies between 8 and $10 \mathrm{~mm}$. Both neurals are elongated, almost hexagonal, and have shorter anterior sides. There is a concavity in the contact surfaces with other neurals.

Costals MCSNC 4381 is an almost complete left costal and the most well-preserved pan-cheloniid remains from Cessaniti (Fig. 3e). The element measures $125 \mathrm{~mm}$ in length, $310 \mathrm{~mm}$ in width, and its thickness is $20 \mathrm{~mm}$. It is rather elongated and its shape is hexagonal. Its anterior margin is convex, whereas its posterior one is slightly concave. On its dorsal surface, there is a "triradiate" sulcus, which represents the margin between two pleurals and one vertebral. MSNC 4594 is the proximal portion of a left costal consisting of 16 different fragments (Fig. 3f, g). The element measures $108.4 \times 62.5 \mathrm{~mm}$, with its thickness varying between 6.0 and $8.3 \mathrm{~mm}$. A slight curvature is observable in lateral view. The suture areas with the neurals and other costals are partially preserved, therefore the measured width of $65.2 \mathrm{~mm}$ represents the original full width of the specimen; the full length of the specimen cannot be estimated. On its dorsal, convex, surface, scute sulci between two vertebrals and the corresponding pleural can be seen. The sulcus between the two vertebrals is located approximately in the middle of the costal. On its ventral, concave, surface, a broken rib process can be observed. MSNC 4595 is a relatively small fragment of a costal, with a maximum length of $83 \mathrm{~mm}$ (Fig. 3h, i). A slight sculpturing pattern, consisting of irregular ridges, is present on its dorsal surface. A broken rib process is evident on the ventral surface of 
this specimen. MSNC 4605 and MSNC 4607 are incomplete costals, with maximum lengths of 113 and $173 \mathrm{~mm}$ respectively.

Hyoplastron MSNC 4549-81 represents a massive right hyoplastron, with a maximum length of $265 \mathrm{~mm}$ and a maximum width of $192 \mathrm{~mm}$ (Fig. 4). Several processes are visible on both its distal margins. Its ventral surface is relatively smooth. The absolute large size and the high degree of ossification indicate that it pertains to an adult individual.

Hypoplastron MSNC 4602 is a fragment of a left hypoplastron (Fig. 5a, b). The specimen is thick. On its dorsal surface, distinct processes are visible, one of which is prominent. Its ventral surface is almost smooth.

Other shell fragments The rest of the shell remains are rather fragmentary and cannot afford a confident anatomical identification. Nevertheless, two of these elements can be more precisely determined as peripheral and plastral fragments (MSNC 4604 and MSNC 4606 respectively). The plastron fragment MSNC 4606 is relatively large, with a maximum preserved length of $151 \mathrm{~mm}$ and a maximum width of $135 \mathrm{~mm}$ (Fig. 5c, d). Several elongated processes appear on its distal edge. Two almost symmetric fractures are visible, especially on its dorsal surface, probably caused due to some taphonomical factor.

Remarks The overall shape and the size of these elements indicate that they pertain to marine turtles. Affinities with pan-dermochelyids can be excluded as all fossil specimens are broad carapace elements and not small ossicles as in the former group (Wyneken 2001; Delfino et al. 2013). Hence, the material is referred to pan-cheloniids. Nevertheless, all these Cessaniti specimens are too fragmentary to afford any precise identification, even at the genus level.

Pan-Testudinoidea Joyce, Parham, and Gauthier, 2004

Pan-Geoemydidae Joyce, 2007

Mauremys Gray, 1869

Mauremys sp.

Figure 6

Material a left hyoplastron (MSNC 4380).
Description MSNC 4380 represents a left hyoplastron embedded in matrix that shows the ventral surface (Fig. 6). The element has a medial length of about $56 \mathrm{~mm}$. Its margins are almost intact, with the exception of the posterior portion of hyo-hypoplastral suture and the bridge with the peripherals, which are damaged. A maximum length of $115 \mathrm{~mm}$ can be estimated for the hyoplastron, measured from the anteriormost point of the epiplastral-hyoplastral suture to the hyo-hypoplastral one. The maximum width, measured hyo-hypoplastral suture to the hyoplastral-peripheral junction, measures $120 \mathrm{~mm}$, while the respective width at the level of the axillary buttress is $86 \mathrm{~mm}$; therefore, the width of the anterior lobe of the plastron can be estimated at about $172 \mathrm{~mm}$. Its anteromedial margin, at the level of the epiplastral-hyoplastral suture, is sinuous and well directed forward. The entoplastral-hyoplastral margin has a wide concavity. There is a slight indentation at the pectoral-abdominal suture. As the specimen is embedded in matrix, it cannot be directly observed how extended was the contact between the axillary buttresses and the costals of the carapace. The humero-pectoral sulcus is sinuous and has an almost horizontal direction from the anterior portion of the entoplastral-hyoplastral suture to the lateral margin of the hyoplastron. The pectoral-abdominal sulcus runs transversely near the hyo-hypoplastral suture and becomes more convex near the mid-width of the specimen and then subsequently concave near the bridge with the peripherals.

Remarks The material can be referred to pan-geoemydids on the basis of the absence of contact between the pectoral-abdominal sulcus and the hyo-hypoplastral suture and the presence of the humero-pectoral sulcus above the entoplastral-hyoplastral suture (Hervet 2000). The specimen can be further assigned to the genus Mauremys on the basis of the presence of reduced axillary notches and concave and broad entoplastral-hyoplastral suture (Hervet 2004). The fragmentary nature of the material does not permit a more precise identification to the species level.

\section{Discussion}

The find and description of the large mammal Stegotetrabelodon syrticus in the Cessaniti area has allowed a reinterpretation about the palaeogeography of the whole Sicilian-Calabrian arch (Siculo-Calabrian arc or Calabrian-Peloritan arc) during the Tortonian, as this elephantid has never been recorded in any other European locality and is exclusively known from Afro-Arabia (Ferretti et al. 2003; Ferretti 2008). Accordingly, Ferretti 
et al. (2003) envisaged that the area of Sicily and Calabria was directly connected to northern Africa, being in fact part of that continent, instead of Europe, during the Tortonian. Such palaeogeographic reconstruction was subsequently supported also by the recent description of an endemic rhinocerotid from Cessaniti, Ceratotherium advenientis which had probably also African affinities (Pandolfi et al. 2019). Nevertheless, finds of the giraffids Bohlinia and Samotherium, as well as the bovid Tragoportax, in Cessaniti complicated more the understanding of the biogeographic origins of this fauna, as these three genera are typical of the so-called Pikermian Biome (i.e., the late Miocene of the southern Balkans and Anatolia), with Bohlinia and Tragoportax also having African representatives (Marra et al. 2011; Marra 2018). These giraffid and bovid finds therefore, prompted for the suggestion of a dispersal and geographic expansion of Pikermian faunal elements towards Africa (Marra et al. 2011, 2017; Marra 2018). This mixture of faunal elements of both African and Pikermian (southeastern European or southwestern Asian) origins render Cessaniti as an ideal case study to test scenarios of biogeographic crossroads and vertebrate dispersals between western Eurasian and sub-Saharan African faunas during the Tortonian late Miocene (Bernor and Rook 2008; Cirilli et al. in press).

Geological studies have indeed suggested a close proximity between the Sicily-Calabria arch and northern Africa, with the former land being located somewhere in the middle of the Central Mediterranean between northern Africa and the Europe (Cirrincione et al. 2015; Broquet 2016). Palaeogeographic reconstructions of the Tortonian Mediterranean region also demonstrate the close geographic proximity (but not unity) of northern Africa to Sicily and Calabria (e.g., Rögl 1999: fig. 12).

Turtles have been variously used to reconstruct and estimate dispersal patterns and biogeographic routes across the Neogene; indeed, dispersals of lineages between Africa and Europe (especially during the early Neogene) have been already suggested for certain turtle taxa, especially when considering the dispersal capabilities of certain chelonian groups (e.g., Georgalis et al. 2013; Georgalis and Kear 2013). The new turtle remains described herein could therefore eventually offer some additional insights on the biogeographic patterns of the Cessaniti fossil assemblage.

Trionychids are present during the late Miocene of the European Mediterranean area, though still they are not abundant faunal elements, while almost all of them are represented by indeterminate fossil specimens that cannot be identified more precisely to the species level (Georgalis and Joyce 2017; Georgalis et al. 2017). The trionychid material from Cessaniti is referred to T. pliocenicus, which remains the sole north Mediterranean extinct taxon and the second currently valid species of Trionyx from the Neogene of Europe. Furthermore, the new Cessaniti material provides a temporal and geographic expansion for this taxon, which was so far only known from the Pliocene of Tuscany. On the basis of their strong anatomical resemblance, it has been suggested that $T$. pliocenicus is a close relative of the extant T. triunguis and apparently pertains to the same lineage (Georgalis and Joyce 2017). Lapparent de Broin (2000) envisaged that the lineage of $T$. triunguis is of Eurasian origin and reached Africa relatively recently, as the only reliable fossil occurrences of this taxon in the latter area are of late Miocene age, i.e., much younger than congeneric records from Europe. Note that other trionychids were present and relatively abundant in Africa, already since the early Miocene, however (when they can be identified more precisely), they all pertain to cyclanorbines, which appears to be the dominant trionychid lineage there, at least until the late Neogene (Georgalis and Joyce 2017). Interestingly, material similar and tentatively referable to the extant $T$. triunguis has been described from the late Miocene of As Sahabi, Libya [Trionyx cf. triunguis of Wood (1987)], a locality which is relatively geographically proximate to Calabria, with the two areas having been also directly terrestrially connected during the Tortonian [note also that As Sahabi is the type locality of the elephantid S. syrticus, i.e., the most prominent shared faunal element between the two localities; Ferretti et al. (2003)]. The new trionychid remains from Cessaniti may allow us to envisage that the ancestor of $T$. pliocenicus dispersed from Calabria to Africa somewhen prior to or during the Tortonian. The Pliocene holotypic record of $T$. pliocenicus from Tuscany may indicate a northward directed geographic expansion of the species following the Messinian Salinity Crisis, though of course we cannot exclude the possibility that the taxon had achieved a larger geographic distribution in the northern Mediterranean margin already by the Tortonian as well. Admittedly, however, the respective northern African trionychid fossil record is rather scarce in order to afford any kind of definite biogeographic conclusions (Georgalis and Joyce 2017), and as such we cannot ascertain with full confidence the precise routes, exact direction, and accurate timing of the dispersal(s) of the T. triunguis lineage to Africa. Nevertheless, even if this biogeographic scheme we propose for T. pliocenicus is correct, it does not fully necessitate that Cessaniti was part of northern Africa during the Tortonian, as trionychids are well known to be capable of marine dispersal; this has been particularly documented also for the extant T. triunguis, living individuals of which have been repeatedly reported to venture in the sea far away from the coast (Taskavak et al. 1999; Corsini-Foka and Masseti 2008). 
Of course, marine turtles such as cheloniids are ubiquitous inhabitants in pelagic and oceanic environments, often achieving also cosmopolitan distributions, hence not affording any useful insights for biogeographic purposes (Lutz et al. 2003). Moreover, the rather fragmentary nature of the Cessaniti material that does not afford a more secure placement even to the genus level, render obscure any further biogeographic conclusions. In any case, the Cessaniti specimens further add to the relatively rich fossil record of marine turtles from Italy (Chesi and Delfino 2006).

As for the single geoemydid specimen from Cessaniti, this seems to be rather interesting from a biogeographic point of view. Mauremys is the most abundant and diverse genus of geoemydids in Europe, spanning a large stratigraphic (Oligocene to Recent) and geographic range and comprising multiple species (de Broin 1977; Lapparent de Broin 2001; Hervet 2004; Danilov 2005). Especially with regard to Italy, the genus is well documented in the fossil record of the country from the Miocene to the Late Pleistocene (Sacco 1889; Portis 1890, 1896; Kotsakis 1981; Delfino and Bailon 2000; Chesi et al. 2007, 2009; Colombero et al. 2017). Mauremys is present also in the extant herpetofauna of Africa, being represented by Mauremys leprosa (Schweigger, 1812), found in the northwestern part of the latter continent (Sindaco and Jeremčenko 2008), whereas on the other side of the Mediterranean, Mauremys rivulata (Valenciennes in Bory de Saint-Vincent 1833) is distributed also in the Levant (Mantziou and Rifai 2014), which was in any case part of Afro-Arabia up to the early Neogene (e.g., Rögl 1999). Contrastingly to the case of Europe, Mauremys appears to be rather rare in the fossil record of Africa; in fact, only rather few fossil specimens of Mauremys have been described from Africa, all of them being of Pliocene or Quaternary age (see Gmira et al. 2013). As such, Miocene records remain therefore so far unknown in Africa (sensu stricto), while even in the broad sense of AfroArabia, they are additionally known solely from the late Miocene of the Arabian Peninsula (a single record from the Tortonian of the United Arabian Emirates; Lapparent de Broin and Van Dijk 1999). Accordingly, if indeed Cessaniti was part of Africa during the Tortonian (Ferretti et al. 2003), then the new Calabrian specimen represents the first genuine late Miocene "African" record of the genus. Nevertheless, even if Calabria was not directly united to Africa during the Tortonian but was simply situated rather close to the latter continent, the Cessaniti specimen still hints that this could be the dispersal route and arrival timing of Mauremys from southern Europe to Africa. It is worth noting that Mauremys is known to be relatively tolerant to salt water and it has been reported to inhabit also brackish waters (Sidis and Gasith 1985;
Mantziou et al. 2004; Vamberger et al. 2014). Accordingly, Mauremys could be capable of dispersals passing through short marine distances, as it has been already suggested to be the case for $M$. rivulata in the Aegean Islands during the Quaternary (Mantziou et al. 2004).

It is thus possible that the area of Calabria played a pivotal biogeographic role for European and African trionychines and geoemydids during the Tortonian. The new remains may witness among the first steps of the lineages of Trionyx triunguis and Mauremys from southern Europe towards Africa during the late Miocene, establishing their presence in the latter area since then. Nevertheless, the marine dispersal capabilities of trionychids and geoemydids (especially of the former) do not really necessitate the existence of a terrestrial connection between Calabria and northern Africa, as potential short marine distances should not represent a true obstacle for these animals. Nevertheless, the same would apply also to the most famous member of the Cessaniti fossil assemblage, the elephantid Stegotetrabelodon, which would follow the opposite direction route (i.e., from Africa to Calabria), taking into consideration that proboscideans are too capable swimmers and have colonized successfully multiple islands environments during the Quaternary of the Mediterranean area (e.g., Van der Geer et al. 2010). More remains are therefore needed in order to test and confirm any biogeographic patterns and palaeogeographic reconstructions with certainty, but it is clearly evident that Cessaniti (and the whole Calabria-Sicily palaeobioprovince) represented a unique biome in Central Mediterranean and played an essential role in a so far poorly documented Tortonian dispersal event between southern Europe and northern Africa.

\section{Conclusions}

The description of chelonian remains from Cessaniti, Calabria, augments our knowledge of the Italian fossil record of turtles. Despite its incompleteness and fragmentary nature of the specimens, the material clearly demonstrates the presence of trionychines, cheloniids, and geoemydids in the late Miocene (Tortonian) of Cessaniti. The identification of Trionyx pliocenicus among the material expands significantly the geographic and temporal distribution of this taxon. On the basis of its large-sized, terrestrial mammal fauna, the locality of Cessaniti has been suggested to represent a faunal crossroad between Europe and Africa, with co-occurring taxa pertaining to both the Pikermian Biome and Afro-Arabia (Ferretti et al. 2003; Marra et al. 2017; Marra 2018; Pandolfi et al. 2019). The new turtle remains cannot fully elucidate whether (or not), to what extent, and for how long, was the Sicily-Calabria arch directly united to Africa and/or Europe during the Tortonian, especially 
when taking into consideration the marine tolerance and dispersal capabilities of certain modern trionychines and geoemydids. Nevertheless, the new Calabrian turtle fossils (particularly T. pliocenicus and Mauremys) further highlight the biogeographic importance of Cessaniti, as they provide substantial information on the potential dispersal route (mainland Europe to Calabria to Africa) and the potential timing of arrival in Africa (Tortonian) of the lineages of T. triunguis and Mauremys.

\section{Acknowledgements}

We thank P. Carone (Tropea), P. Mazza (Firenze), and A.C. Marra (Messina) for discussion and field work at Cessaniti and the late Angelo Varola (Lecce) for the preparation of MSNC 4594. Background field work for this work has been supported by the University of Florence and NGS (8788-10) to LR. Study of extant and extinct turtle specimens for comparative purposes was made possible through travel support grants SYNTHESYS GB-TAF-6591 and SYNTHESYS AT-TAF-5911 to GLG and AT-TAF-1281 to MD and the respective curators of the holding institutions (Sandra Chapman, Silke Schweiger, and Ursula Göhlich) are highly thanked here. Project supported by Fondi di Ateneo dell'Università di Torino (2018-2019), Generalitat de Catalunya (CERCA Program) and Spanish Agencia Estatal de Investigación (CGL2016-76431-P, AEI/FEDER, EU) to MD. We finally thank the Editor Daniel Marty and the two reviewers, Walter Joyce and an anonymous one, whose comments improved the quality of the manuscript.

\section{Authors' contribution}

GLG wrote the text and prepared the figures. Gl collected, prepared, and photographed the specimens and wrote part of the geological settings. LR collected the specimens and wrote part of the geological settings. FS collected the specimens. MD wrote the text and collected the specimens. All authors read and approved the final manuscript.

\section{Competing interests}

The authors declare that they have no competing interests.

\section{Author details}

${ }^{1}$ Dipartimento di Scienze della Terra, Università di Torino, Via Valperga Caluso 35, 10125 Turin, Italy. ${ }^{2}$ Museo Civico di Storia Naturale di Comiso, Via degli Studi 9, 97013 Comiso, Italy. ${ }^{3}$ Dipartimento di Scienze della Terra, Università di Firenze, Via G. La Pira 4, 50121 Florence, Italy. ${ }^{4}$ Museo della Fauna del Dipartimento di Scienze Veterinarie dell'Università degli Studi di Messina, Polo Universitario SS. Annunziata, 98100 Messina, Italy. ${ }^{5}$ Universitat Autònoma de Barcelona, Edifici ICTAICP, Carrer de les Columnes s/n, Campus de la UAB, 08193 Cerdanyola del Vallès, Barcelona, Spain.

Received: 1 November 2019 Accepted: 7 January 2020

Published online: 11 February 2020

\section{References}

Batsch, A. J. G. K. (1788). Versuch einer Anleitung, zur Kenntniß und Geschichte der Thiere und Mineralien, für akademische Vorlesungen entworfen, und mit den nöthigsten Abbildungen versehen, Erster Theil. Allgemeine Geschichte der Natur; besondre der Saügthiere, Vögel, Amphibien und Fische (pp. 528). Jena: Akademische Buchhandlung.

Bernor, R. L., \& Rook, L. (2008). A current view of Sahabi large mammal biogeographic relationships. Garyounis Scientific Bulletin, Special Issue, 5, 285-292.

Broquet, P. (2016). Sicily in its Mediterranean geological frame. Boletín Geológico y Minero, 127, 547-562.

Carnevale, G., Gennari, R., Lozar, F., Natalicchio, M., Pellegrino, L., \& Dela Pierre, F. (2019). Living in a deep desiccated Mediterranean Sea: An overview of the Italian fossil record of the Messinian salinity crisis. Bollettino della Società Paleontologica Italiana, 58, 109-140.

Carone, G., \& Domning, D. P. (2007). Metaxytherium serresii (Mammalia: Sirenia): new pre-Pliocene record, and implications for Mediterranean paleoecology before and after the Messinian Salinity Crisis. Bollettino della Società Paleontologica Italiana, 46, 55-92.

Chesi, F. (2009). II registro fossile italiano dei cheloni [dissertation] (pp. 178). Florence: Università di Firenze.

Chesi, F., \& Delfino, M. (2006). The Italian fossil record of the sea turtles. In: Atti del $6^{\circ}$ Congresso Nazionale della Societas Herpetologica Italica, 2006, pp. $95-116$.

Chesi, F., Delfino, M., Abbazzi, L., Carboni, S., Lecca, L., \& Rook, L. (2007). New fossil vertebrate remains from San Giovanni di Sinis (Late Pleistocene, Sardinia): the last Mauremys (Reptilia, Testudines) in the central Mediterranean. Rivista Italiana di Paleontologia e Stratigrafia, 113, 287-297.

Chesi, F., Delfino, M., \& Rook, L. (2009). Late Miocene Mauremys (Testudines, Geoemydidae) from Tuscany (Italy): evidence of terrapin persistence after a mammal turnover. Journal of Paleontology, 83, 379-388.

Cirilli, O., Zouhri, S., El Boughabi, S., Benvenuti, M. G., Papini, M., Bernor, R. L., \& Rook L. (in press). The hipparionine horses (Perissodactyla: Mammalia) from the late Miocene of Tizin'Tadderht (Southern Ouarzazate Basin; Central High Atlas; Morocco). Rivista Italiana di Paleontologia e Stratigrafia, 126

Cirrincione, R., Fazio, E., Fiannacca, P., Ortolano, G., Pezzino, A., \& Punturo, R. (2015). The Calabria-Peloritani Orogen, a composite terrane in Central Mediterranean; its overall architecture and geodynamic significance for a pre-Alpine scenario around the Tethyan basin. Periodico di Mineralogia, $84,701-749$

Colombero, S., Alba, D. M., D'Amico, C., Delfino, M., Esu, D., Giuntelli, P., et al. (2017). Late Messinian mollusks and vertebrates from Moncucco Torinese, north-western Italy Paleoecological and paleoclimatological implications. Palaeontologia Electronica, 20, 1-66.

Corsini-Foka, M., \& Masseti, M. (2008). On the oldest record of the Nile softshelled turtle, Trionyx triunguis (Forskål, 1775), in the Eastern Aegean islands (Greece). Zoology in the Middle East, 43, 108-110.

Danilov, I. G. (2005). Die fossilen Schildkröten Europas. In U. Fritz (Ed.), Handbuch der Reptilien und Amphibien Europas; Part 3/IIIB: Schildkröten (Testudines) II (pp. 329-448). Wiebelsheim: AULA.

de Broin, F. (1977). Contribution à l'étude des Chéloniens: Chéloniens continentaux du Crétacé et du Tertiaire de France. Mémoires du Muséum National d'Histoire Naturelle, Série C, 38, 1-366.

de Lapparent de Broin, F. (2000). African chelonians from the Jurassic to the present: phases of development and preliminary catalogue of the fossil record. Paleontologia Africana, 36, 43-82.

de Lapparent de Broin, F. (2001). The European turtle fauna from the Triassic to the Present. Dumerilia, 4, 155-216.

de Lapparent de Broin, F., \& de Dijk, P. (1999). Chelonia from the Late Miocene Baynunah Formation, Emirate of Abu Dhabi, United Arab Emirates: palaeogeographical implications. In P. J. Whybrow \& A. Hill (Eds.), Fossil Vertebrates of Arabia (pp. 136-162). New Haven: Yale University Press.

Delfino, M. (2002). Erpetofaune italiane del Neogene e del Quaternario [dissertation] (pp. 382). Modena and Reggio Emilia: University of Modena and Reggio Emilia.

Delfino, M., \& Bailon, S. (2000). Early Pleistocene herpetofauna from Cava Dell' Erba and Cava Pirro (Apulia, Southern Italy). Herpetological Journal, 10, $95-110$.

Delfino, M., Rage, J.-C., Bolet, A., \& Alba, D. M. (2013a). Early Miocene dispersal of the lizard Varanus into Europe: reassessment of vertebral material from Spain. Acta Palaeontologica Polonica, 58, 731-735.

Delfino, M., Rage, J.-C., \& Rook, L. (2003). Tertiary mammal turnover phenomena: what happened to the herpetofauna? In J. W. F. Reumer \&W. Wessels (Eds.), Distribution and migration of Tertiary mammals in Eurasia: a volume in honour of Hans de Bruijn, Deinsea (Vol. 10, pp. 153-161). Natuurmuseum: Rotterdam.

Delfino, M., Scheyer, T. M., Chesi, F., Fletcher, T., Gemel, R., Macdonald, S., et al. (2013b). Gross morphology and microstructure of type locality ossicles of Psephophorus polygonus Meyer, 1847 (Testudines, Dermochelyidae). Geological Magazine, 150, 767-782.

Ferretti, M. P. (2008). Miocene proboscideans from Italy: African elements and palaeogeographic implications. Geology of East Libya, 3, 325-334.

Ferretti, M. P., Rook, L. \& Torre, D. (2003). Stegotetrabelodon (Proboscidea, Elephantidae) from the late Miocene of southern Italy. Journal of Vertebrate Paleontology, 23, 659-666.

Forskål, P. (1775). Descriptiones Animalium. Avium, Amphibiorum, Piscium, Insectorum, Vermium: Quae in Itinere Oriental Observavit (p. 12). Haunia: Mölleri. 
Freudenthal, M. (1971). Neogene vertebrates from the Gargano Peninsula, Italy. Scripta Geologica, 13, 1-10.

Freudenthal, M. (1972). Deinogalerix koenigswaldi nov. gen., nov. sp., a giant insectivore from the Neogene of Italy. Scripta Geologica, 14, 1-19.

Freudenthal, M., \& Martín-Suárez, E. (2010). The age of immigration of the vertebrate faunas found at Gargano (Apulia, Italy) and Scontrone (I'Aquila, Italy). Comptes Rendus Palevol, 9, 95-100.

Fucini, A. (1912). Trionyx pliocenicus Law. Paleontographia Italica, 18, 1-28.

Geoffroy Saint-Hilaire, E. F. (1809). Mémoire sur les tortues molles, nouveau genre sous le nom de Trionyx, et sur la formation des carapaces. Annales du Muséum d'Histoire Naturelle, 14, 1-20.

Georgalis, G. L., \& Joyce, W. G. (2017). A review of the fossil record of Old World turtles of the clade Pan-Trionychidae. Bulletin of the Peabody Museum of Natural History, 58, 115-208.

Georgalis, G. L., \& Kear, B. P. (2013). The fossil turtles of Greece: an overview of taxonomy and distribution. Geobios, 46, 299-311.

Georgalis, G. L., Velitzelos, E., Velitzelos, D., \& Kear, B. P. (2013). Nostimochelone lampra gen. et sp. nov., an enigmatic new podocnemidoidean turtle from the lower Miocene of northern Greece. In D. Brinkman, P. Holroyd, \& J. Gardner (Eds.), Morphology and evolution of turtles: papers in honor of Eugene S Gaffney, Pleurodires (Vol. 3, pp. 277-287). Dordrecht: Springer.

Georgalis, G. L., Villa, A., \& Delfino, M. (2016a). First description of a fossil chamaeleonid from Greece and its relevance for the European biogeographic history of the group. The Science of Nature, 103, 12.

Georgalis, G. L., Villa, A., Ivanov, M., Roussiakis, S., Skandalos, P., \& Delfino, M. (2019a). Early Miocene herpetofaunas from the Greek localities of Aliveri and Karydia—bridging a gap in the knowledge of amphibians and reptiles from the early Neogene of southeastern Europe. Historical Biology, 31, 1045-1064.

Georgalis, G. L., Villa, A., Ivanov, M., Vasilyan, D., \& Delfino, M. (2019b). Fossil amphibians and reptiles from the Neogene locality of Maramena (Greece), the most diverse European herpetofauna at the Miocene/Pliocene transition boundary. Palaeontologia Electronica, 22.3.68, 1-99.

Georgalis, G. L., Villa, A., Vlachos, E., \& Delfino, M. (2016b). Fossil amphibians and reptiles from Plakias, Crete: a glimpse into the earliest late Miocene herpetofaunas of southeastern Europe. Geobios, 49, 433-444.

Georgalis, G. L., Zoboli, D., Pillola, G. L., \& Delfino, M. (2017). A revision of the trionychid turtle Procyclanorbis sardus Portis, 1901 from the late Miocene of Sardinia (Italy). Annales de Paléontologie, 103, 127-134.

Gmira, S., Lapparent de Broin, F., Geraads, D., Lefèvre, D., Mohib, A., \& Raynal, J. P. (2013). Les tortues du Pliocène d'Ahl al Oughlam (Casablanca, Maroc) et de localités Mio-Pliocènes avoisinantes. Geodiversitas, 35, 691-733.

Gramigna, P., Guido, A., Mastandrea, A., \& Russo, F. (2008). The paleontological site of Cessaniti: a window on a coastal marine environment of seven million years ago (Southern Calabria, Italy). Geologica Romana, 41, 25-34.

Gray, J. E. (1869). Description of Mauremys laniaria, a new freshwater tortoise. Proceedings of the Zoological Society of London, 1869, 499-500.

Hervet, S. (2000). Tortues du Quaternaire de France: critères de détermination, répartitions chronologique et géographique. Mésogée, 58, 3-47.

Hervet, S. (2004). Systématique du groupe "Palaeochelys sensu lato-Mauremys" (Chelonii, Testudinoidea) du Tertiaire d'Europe occidentale: principaux résultats. Annales de Paléontologie, 90, 13-78.

Hsü, K. J. (1972). When the Mediterranean dried up. Scientific American, 227, 44-51.

Joyce, W. G. (2007). Phylogenetic relationships of Mesozoic turtles. Bulletin of the Peabody Museum of Natural History, 48, 3-102.

Joyce, W. G., Parham, J. F., \& Gauthier, J. A. (2004). Developing a protocol for the conversion of rank-based taxon names to phylogenetically defined clade names, as exemplified by turtles. Journal of Paleontology, 78, 989-1013.

Kotsakis, T. (1981). Gli anfibi e i rettili dei Pleistocene del Lazio (Italia Centrale). Geologica Romana, 20, 57-67.

Koufos, G. D., Kostopoulos, D., \& Vlachou, T. (2005). Neogene/Quaternary mammalian migrations in Eastern Mediterranean. Belgian Journal of Zoology, $135,181-190$

Koufos, G. D., Zouros, N., \& Mourouzidou, O. (2003). Prodeinotherium bavaricum (Proboscidea, Mammalia) from Lesvos island, Greece; the appearance of deinotheres in the Eastern Mediterranean. Geobios, 36, 305-315.

Lutz, P. L., Musick, J. A., \& Wyneken, J. (2003). The biology of sea turtles (Vol. II, p. 455). Boca RatoN: CRC Press.
Lymberakis, P., \& Poulakakis, N. (2010). Three continents claiming an archipelago: The evolution of Aegean's Herpetofaunal Diversity. Diversity, 2, 233-255.

Mantziou, G., Poulakakis, N., Lymberakis, P., Valakos, E., \& Mylonas, M. (2004). The inter- and intraspecific status of Aegean Mauremys rivulata (Chelonia, Bataguridae) as inferred by mitochondrial DNA sequences. Herpetological Journal, 14, 35-45.

Mantziou, G., \& Rifai, L. (2014). Mauremys rivulata (Valenciennes in Bory de Saint-Vincent 1833)—Western Caspian Turtle, Balkan Terrapin. In A. G. J. Rhodin, P. C. H. Pritchard, P. P. van Dijk, R. A. Saumure, K. A. Buhlmann, J. B. Iverson, \& R. A. Mittermeier (Eds.), Conservation biology of freshwater turtles and tortoises: a compilation project of the IUCN/SSC tortoise and freshwater turtle specialist group (Vol. 5, pp. 1-9)., Chelonian Research Monographs Chelonian Research Foundation: Lunenburg.

Marra, A. C. (2018). Tragoportax cf. rugosifrons (Schlosser, 1904) from the late Miocene of Cessaniti (Southern Italy). Comptes Rendus Palevol, 17, 378-387.

Marra, A. C., Carone, G., Agnini, C., Ghinassi, M., Oms, O., \& Rook, L. (2017). Stratigraphic and chronologic framework of the Upper Miocene Cessaniti succession (Vibo Valentia, Calabria, Italy). Rivista Italiana di Paleontologia e Stratigrafia, 123, 379-393.

Marra, A. C., Carone, G., \& Bianucci, G. (2016). Sperm whale teeth from the late Miocene of Cessaniti (Southern Italy). Bollettino della Società Paleontologica Italiana, 55, 223-225.

Marra, A. C., Solounias, N., Carone, G., \& Rook, L. (2011). Palaeogeographic significance of the giraffid remains (Mammalia, Arctiodactyla) from Cessaniti (Late Miocene, Southern Italy). Géobios, 44, 189-197.

Meulenkamp, J. E., \& Sissingh, W. (2003). Tertiary palaeogeography and tectonostratigraphic evolution of the Northern and Southern Peri-Tethys platforms and the intermediate domains of the African-Eurasian convergent plate boundary zone. Palaeogeography, Palaeoclimatology, Palaeoecology, $196,209-228$

Montcharmont Zei, M., \& Montcharmont, U. (1987). Metaxytherium medium nelle arenarie tortoniane di Santa Domenica di Ricadi (Catanzaro). Memorie di Scienze Geologiche, 29, 285-341.

Neviani, A. (1886). Sui giacimenti dei Cetacei fossili del monteleonese, con indicazioni di altri rinvenimenti nelle Calabrie. Bollettino Della Società Geologica Italiana, 5, 61-73.

Nicotera, P. (1959). Rilevamento geologico del versante settentrionale del monte Poro (Calabria). Memorie e Note dell'Istituto di Geologia Applicata di Napoli, 7, 1-92.

Ogniben, L. (1973). Schema geologico della Calabria in base ai dati odierni. Geologica Romana, 12, 243-585.

Pandolfi, L., Marra, A. C., Carone, G., Maiorino, L., \& Rook, L. (2019). A new rhinocerotid (Mammalia, Rhinocerotidae) from the latest Miocene of Southern Italy. Historical Biology. https://doi.org/10.1080/08912 963.2019.1602615.

Peters, K. F. (1855). Schildkrötenreste aus den österreichischen TertiärAblagerungen. Denkschriften der Kaiserlichen Akademie der Wissenschaften, mathematisch-naturwissenschaftliche Classe, 9, 1-22.

Portis, A. (1890). I rettili pliocenici del Valdarno superiore e di alcune altre località plioceniche di Toscana (p. 32). Florence: Le Monnier.

Portis, A. (1896). Contribuzioni alla storia fisica del bacino di Roma e studii sopra l'estenzione da darsi al Pliocene superiore (p. 513). Roma: L. Roux.

Rage, J.-C. (2013). Mesozoic and Cenozoic squamates of Europe. Palaeobiodiversity and Palaeoenvironments, 93, 517-534.

Rögl, F. (1999). Mediterranean and paratethys. Facts and hypotheses of an Oligocene to Miocene paleogeography (short overview). Geologica Carpathica, 50, 330-349.

Rook, L. (2016). Geopalaeontological setting, chronology and palaeoenvironmental evolution of the Baccinello-Cinigiano Basin continental successions (Late Miocene, Italy). Comptes Rendus Palevol, 15, 825-836.

Rook, L., Abbazzi, L., Chesi, F., Delfino, M., Ferretti, M. P., \& Gallai, G. (2008). The Italian record of latest Miocene continental vertebrates. Bollettino della Società Paleontologica Italiana, 47, 191-194.

Rook, L., Gallai, G., \& Torre, D. (2006). Lands and endemic mammals in the Late Miocene of Italy: constrains for paleogeographic outlines of Tyrrhenian area. Palaeogeography, Palaeoclimatology, Palaeoecology, 238, 263-269.

Sacco, F. (1889). I Cheloni astiani del Piemonte. Memorie della Reale Accademia delle Scienze di Torino, 39, 427-461. 
Schweigger, A. F. (1812). Prodromus Monographiae Cheloniorum. Königsberger Archiv für Naturwissenschaften und Mathematik, 1, 271-368.

Sidis, I., \& Gasith, A. (1985). Food habits of the Caspian terrapin (Mauremys caspica rivulata) in unpolluted and polluted habitats in Israel. Journal of Herpetology, 19, 108-115.

Sindaco, R., \& Jeremčenko, V. (2008). The Reptiles of the Western Palearctic. Vol. 1. Annotated Checklist and Distributional Atlas of the Turtles, Crocodiles, Amphisbaenians and Lizards of Europe, North Africa, Middle East and Central Asia (p. 580). Belvedere: Monografie della Societas Herpetologica Italica I.

Stara, P., \& Marini, F. (2018). Amphiope caronei n. sp. (Echinoidea Astriclypeidae) from the Tortonian of Cessaniti, Vibo Valentia Province (Calabria, Italy). Biodiversity Journal, 9, 73-88.

Taskavak, E., Reimann, M. J., \& Polder, W. N. (1999). First record of the Nile softshelled Turtle, Trionyx triunguis, from Kos Island, Greece, with comments on its occurrence in the eastern Mediterranean. Chelonian Conservation and Biology, 3, 510-512.

Torres-Roig, E., Bailon, S., Bover, P., \& Alcover, J. A. (2017). An early Pliocene anuran assemblage from Mallorca (Balearic Islands, Western Mediterranean): palaeobiogeographicand palaeoenvironmental implications. Palaeobiodiversity and Palaeoenvironments, 97, 315-327.
Valenciennes, A. (1833). [Emys rivulata]. In: G. Bibron, \& J. B. G. M. Bory de SaintVincent (Eds.), Vertébrés à sang froid. Reptiles et poissons. Reptiles. Expédition Scientifique de Morée, Tome III. 1 re partie, Zoologie.

Vamberger, M., Stuckas, H., Ayaz, D., Lymberakis, P., Široký, P., \& Fritz, U. (2014). Massive transoceanic gene flow in a freshwater turtle (Testudines: Geoemydidae: Mauremys rivulata). Zoologica Scripta, 43, 313-322.

Van der Geer, A., Lyras, G., de Vos, J., \& Dermitzakis, M. (2010). Evolution of Island Mammals: Adaptation and Extinction of Placental Mammals on Islands ( $p$. 496). Oxford: Wiley.

Wood, R. C. (1987). Fossil turtles from the Sahabi Formation. In N. T. Boaz, A. El-Amauti, A. W. Gaziry, J. de Heinzelin, \& D. Dechant Boaz (Eds.), Neogene Palaeontology and Geology of Sahabi (pp. 107-112). New York: Alan R. Liss. Wyneken, J. (2001). The anatomy of sea turtles (p. 172). U.S. Department of Commerce NOAA Technical Memorandum NMFS-SEFSC-470: US Department of Commerce NOAA.

\section{Publisher's Note}

Springer Nature remains neutral with regard to jurisdictional claims in published maps and institutional affiliations.

\section{Submit your manuscript to a SpringerOpen ${ }^{\circ}$ journal and benefit from:}

- Convenient online submission

- Rigorous peer review

- Open access: articles freely available online

- High visibility within the field

- Retaining the copyright to your article

Submit your next manuscript at $\mathbf{s p r i n g e r o p e n . c o m ~}$ 